\title{
COMPARATIVE STUDY OF WIND FARM STABILIZATION USING VARIABLE SPEED GENERATOR AND FACTS DEVICE
}

\author{
K.E. Okedu ${ }^{1 *}$, S.M. Muyeen ${ }^{2}$, Rion Takahashi ${ }^{1}$, and Junji Tamura ${ }^{1}$ \\ kenokedu@yahoo.com \\ ${ }^{1}$ Department of Electrical and Electronic Engineering, Kitami Institute of Technology, Japan. \\ ${ }^{2}$ Department of Electrical Engineering, The Petroleum Institute, Abu Dhabi, U.A.E.
}

\section{ABSTRACT}

Recently, the grid codes require taking into account the reactive power of the wind farm in order to contribute to the network stability during grid fault, thus operating the wind farm as active compensator devices. This paper presents a comparative study of stabilizing a wind farm with variable speed wind turbine generator system that use doubly fed induction generator (DFIG) as the wind generator and a flexible ac transmission system (FACTS) like the static synchronous compensator (STATCOM). Simulation results show that the wind farm could be effectively stabilized with both systems, but at a reduced cost with the DFIG system.

Index Terms - Wind energy, Grid fault, DFIG, STATCOM, Induction generator.

\section{INTRODUCTION}

It is increasingly important that electrical power generation using wind energy continue to operate during periods of short circuit fault in the grid as per recent wind farm grid code. The penetration of wind power to the grid has reached levels high enough to affect the quality and stability of the grid [1]. According to grid codes set by utilities, tripping of wind turbine generators systems (WTGSs) following grid fault is not allowed. Besides to provide voltage support to the grid, mandatory reactive current control is necessary. Main ancillary services in a power system are power-frequency control and voltage control. These services must be provided by each generator connected to the grid. In order to provide the ancillary service of voltage, generators must have some reactive power capability as required by the corresponding grid codes.

DFIG has shown better behavior concerning system stability during short-circuit faults in comparison to IG [2], because of its capability of decoupling the control of output active and reactive powers. The superior dynamic performance of the DFIG results from the frequency converter which typically operates with sampling and switching frequencies of above $2 \mathrm{kHz}$ [3].

There are various voltage source or current source inverter based on FACTS devices for flexible power control damping of power system and stabilization of wind generators [4], however, in this work STATCOM based on a voltage source converter (VSC) PWM technique is used to stabilize the IGs in the wind farm in comparison to the use of the DFIGs.
This paper presents a comparative analysis of the use of DFIGs and STATCOM to stabilize a wind farm. Simulation model of wind turbine with DFIGs and IGs developed in PSCAD/EMTDC [5] is presented.

\section{MODELING OF WIND TURBINE}

The captured power from the wind can be expressed as equation (1). Tip speed ratio, $\lambda$ and power coefficient, $C_{p}$ can be expressed as equations (2) and (3) as shown below [6].

$$
\begin{aligned}
& P_{w t b}=0.5 \rho C_{p}(\lambda, \beta) \pi R^{2} V_{w}{ }^{3}[W] \\
& C_{p}(\lambda, \beta)=0.5\left(\Gamma-0.022 \beta^{2}-5.6\right) e^{-0.17 \Gamma} \\
& \lambda=\frac{\omega_{w t b} R}{V_{w}} \\
& \Gamma=\frac{R(3600)}{\lambda(1609)}
\end{aligned}
$$

The torque coefficient and the turbine torque are expressed as follows.

$$
\begin{aligned}
C_{t} & =\frac{C_{p}(\lambda)}{\lambda} \\
T_{M} & =0.5 \rho C_{t}(\lambda) \pi R^{3} V_{w}{ }^{2}[\mathrm{NM}]
\end{aligned}
$$

Where, $P_{w t b}$ is the extracted power from the wind, $\rho$ is the air density $\left[\mathrm{kg} / \mathrm{m}^{3}\right], \mathrm{R}$ is the blade radius $[\mathrm{m}], V_{w}$ is wind speed $[\mathrm{m} / \mathrm{s}]$, blade pitch angle is $\beta[\mathrm{deg}], \omega_{w t b}$ is the rotational speed $[\mathrm{rad} / \mathrm{s}]$, and $T_{M}$ is the wind turbine output torque $[\mathrm{Nm}]$.

Figures 1 and 2 show the wind turbine characteristics used for this study for both IG and DFIG respectively. Equations (7)-(9) are used for the regulation of the active power output $P_{\text {ref }}$, the rotor speed $\omega_{\text {ropt }}$ value and its regulation during wind speed change between $0.7 \mathrm{pu}$ to $1.3 \mathrm{pu}$ in Figure 2. Figure 3 shows the control block for regulating the reference active power

$P_{\text {ref } 1}=0.1571 V_{w}-1.035[\mathrm{pu}]$

$P_{\text {ref } 2}=0.2147 V_{w}-1.668[\mathrm{pu}]$

$\omega_{\text {ropt }}=0.0775 V_{w}[\mathrm{pu}]$

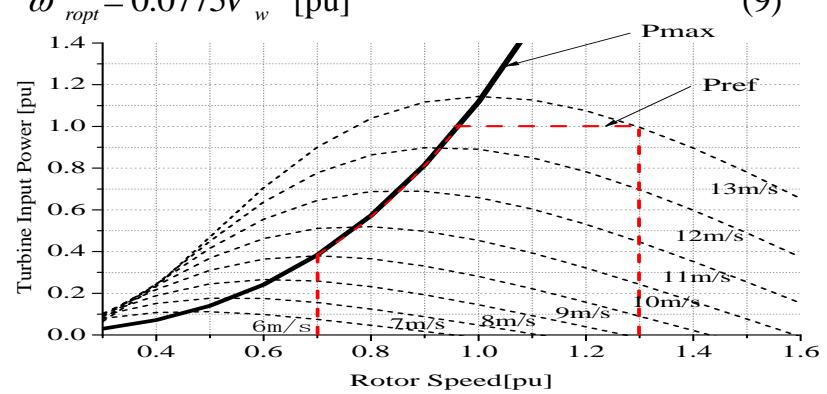

Figure 1. Turbine characteristic of DFIG with maximum power point tracking (MPPT) 


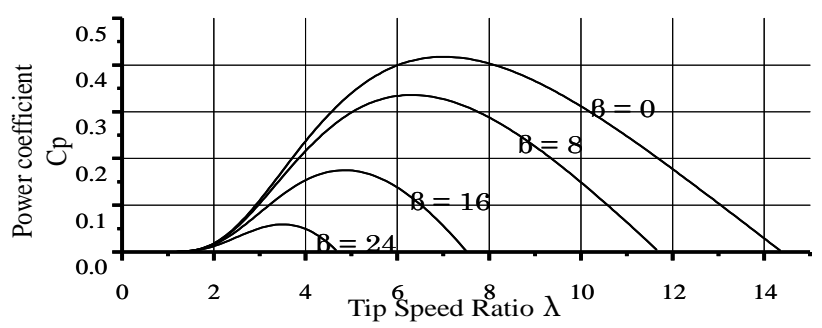

Figure 2. $\mathrm{C}_{\mathrm{P}^{-}} \lambda$ curves for different pitch angles for IG

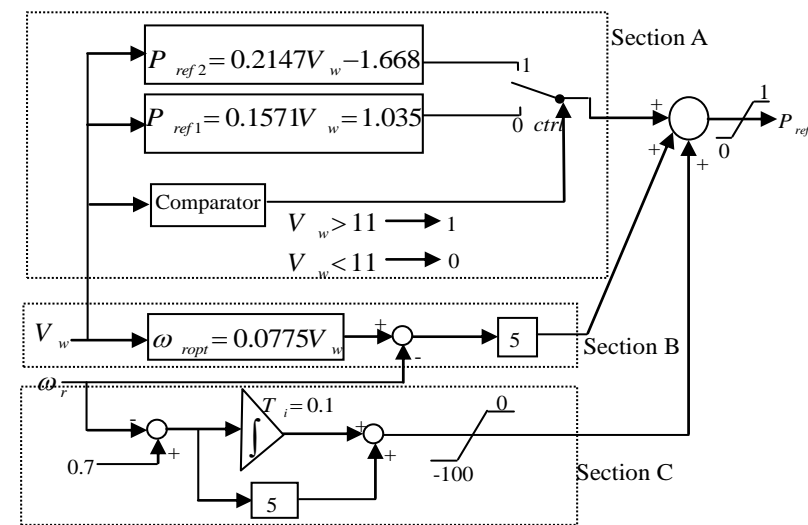

Figure 3. MPPT control block to determine $P_{\text {ref }}$

Figures 4 and 5 respectively show the pitch angle controllers for the IGs and the DFIGs used in this study.

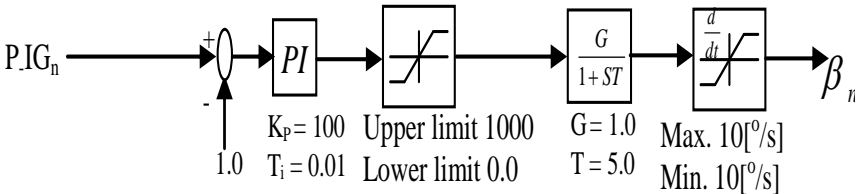

Figure 4. Pitch controller for the induction generators

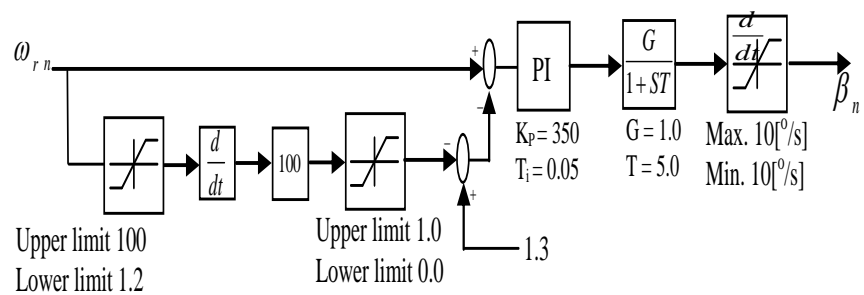

Figure 5. Pitch controller for the DFIGs

\section{MODEL SYSTEM OF STUDY}

The model system for this study is shown in Figure 6 where the wind farm is composed of 2 aggregated DFIGs each of capacity $12.5 \mathrm{MVA}$. The wind farm capacity in this case is 50MVA. The two DFIGs (25MVA) are 50\% of the wind farm. For the second case, the wind farm is composed of only 2 aggregated IGs each of capacity 12.5MVA, without any reactive compensation device connected at the point of the common coupling (PCC) as shown in Figure 7. The total capacity of the wind farm in this case is 25MVA. The third case (Figure 8) considers a wind farm of two aggregated IGs each of capacity 12.5MVA, with a STATCOM connected at the PCC. Table 1 shows the parameters of the DFIGs and IGs [6].

\section{DFIG AND STATCOM CONTROL SYSTEMS}

The Rotor side converter and the Grid side converter control blocks for the DFIGs are shown in Figures 9 and 10 respectively. In Figure 9, the rotor side converter controls the terminal (grid) voltage to $1.01 \mathrm{pu}$. The d-axis-

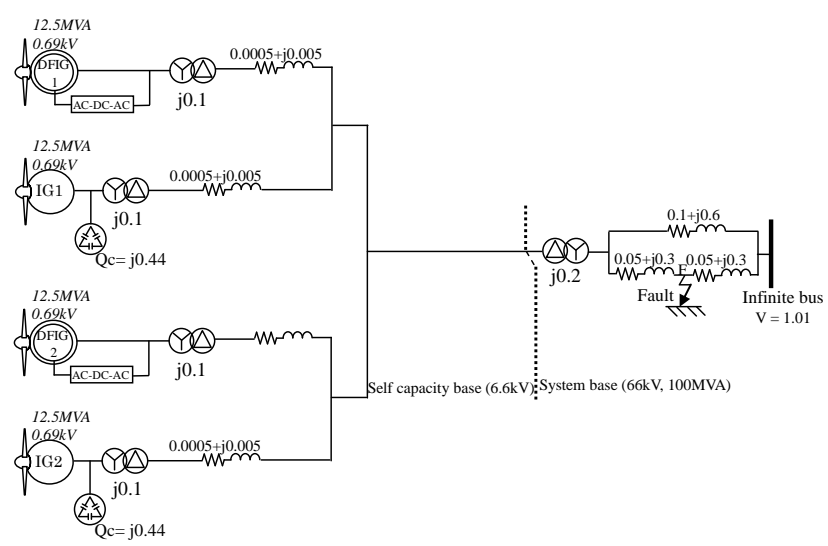

Figure 6. Wind farm model for DFIGs and IGs (Case 1)

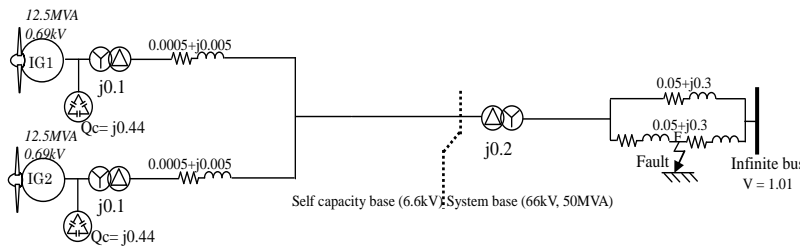

Figure 7. Wind farm model for only IGs (Case 2)

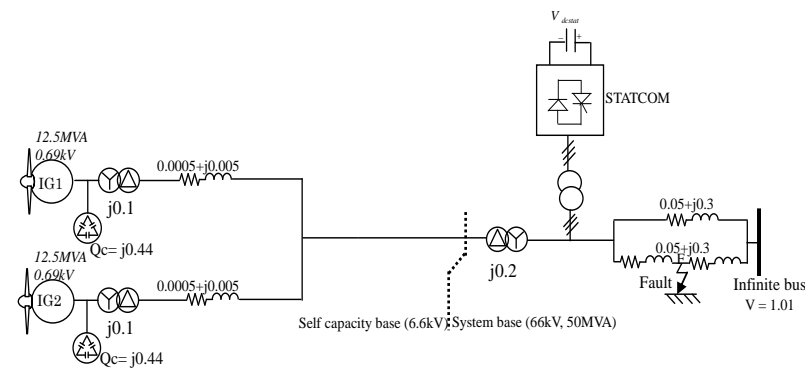

Figure 8. Wind farm model with STATCOM (Case 3)

Table 1. Parameters of the IGs and DFIGs

\begin{tabular}{|l|l|l|}
\hline Generator Type & IG & DFIG \\
\hline Rated Voltage & $690 \mathrm{~V}$ & $690 \mathrm{~V}$ \\
\hline Stator Resistance & $0.01 \mathrm{pu}$ & $0.01 \mathrm{pu}$ \\
\hline $\begin{array}{l}\text { Stator Leakage } \\
\text { Reactance }\end{array}$ & $0.07 \mathrm{pu}$ & $0.15 \mathrm{pu}$ \\
\hline $\begin{array}{l}\text { Magnetizing } \\
\text { Reactance }\end{array}$ & $4.1 \mathrm{pu}$ & $3.5 \mathrm{pu}$ \\
\hline Rotor Resistance & $0.007 \mathrm{pu}$ & $0.01 \mathrm{pu}$ \\
\hline $\begin{array}{l}\text { Rotor leakage } \\
\text { Reactance }\end{array}$ & $0.07 \mathrm{pu}$ & $0.15 \mathrm{pu}$ \\
\hline Inertia Constant & $1.5 \mathrm{secs}$ & $1.5 \mathrm{secs}$ \\
\hline
\end{tabular}

-current controls the active power, while the q-axis current controls the reactive power. After dq0-to-abc transformation, $V_{d r}{ }^{*}$ and $V_{q r}{ }^{*}$ are sent to the PWM signal generator and $V^{*}{ }_{a b c}$ are the three-phase voltages desired at the rotor side converter output as shown in the converter configuration circuit. Also, Figure 10 shows the control block for the GSC control, where PLL provides the angle $\theta_{P L L}$ and $\theta_{s}$ is the effective angle for the abc-to-dq0 (and dq0-to-abc) transformation. The direct axis component is used to regulate the dc-link voltage $\left(E_{d c}\right)$ to $1.0 \mathrm{pu}$. The d-axis current controls the DC-Link voltage, while the q-axis current controls the reactive power of the grid side converter. After a dq0- toabc transformation, $V_{q}{ }^{*}$ and $V_{d}{ }^{*}$ are sent to the PWM signal generator. Finally $V_{a b c}{ }^{*}$ are three voltages at the 
GSC output for the IGBT's switching. The circuit configuration of the rotor side, dc-link and the grid-side converter is given in Figure 11, while Table 2 gives the ratings of the excitation circuit [6].

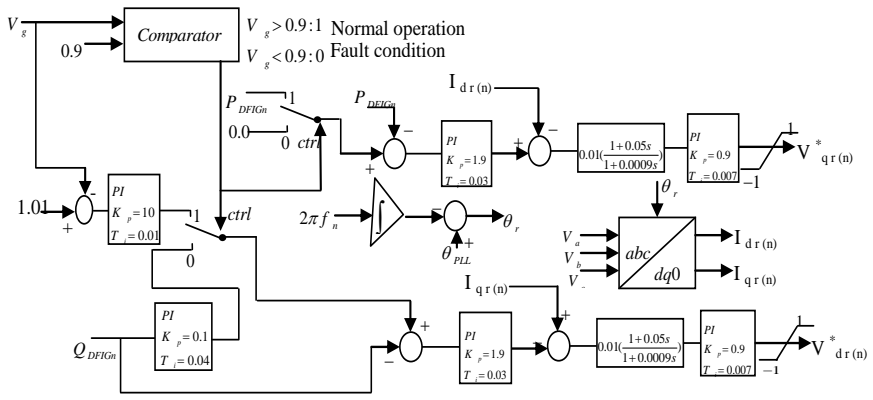

Figure 9. Control block for the rotor side converter

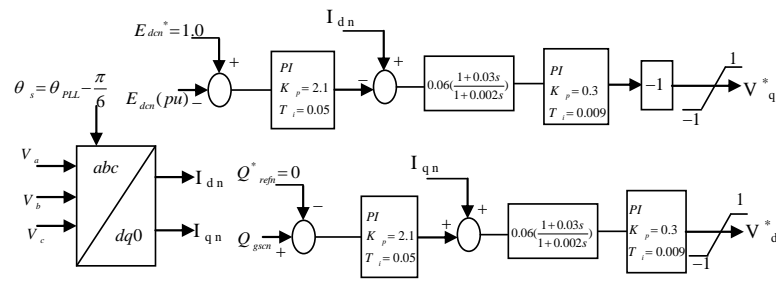

Figure 10. Control block for the grid side converter

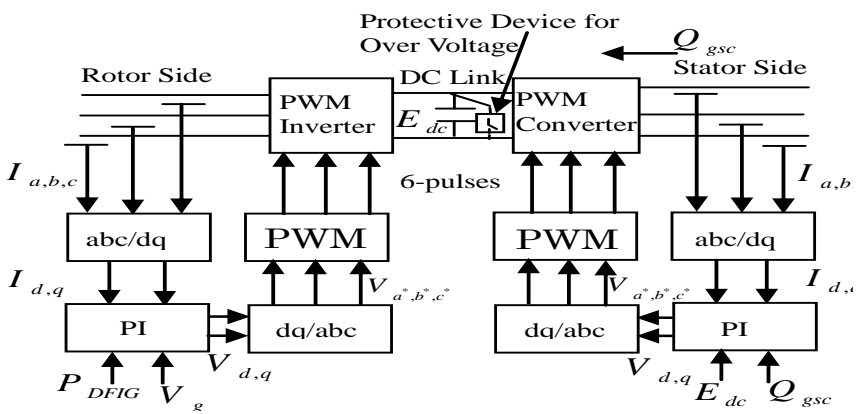

Figure 11. Circuit configuration of DFIG power converters

Table 2. Ratings and parameters of excitation circuit of DFIGs

\begin{tabular}{|c|c|}
\hline DC link voltage & $1.5 \mathrm{kV}$ \\
\hline DC link capacitor & $50,000 \mu \mathrm{F}$ \\
\hline Device for power converter & IGBT \\
\hline PWM carrier frequency & $2 \mathrm{kHz}$ \\
\hline $\begin{array}{c}\text { Upper limit of DC voltage } \\
\text { (EDC_Max) }\end{array}$ & $1.65 \mathrm{kV}(110 \%)$ \\
\hline $\begin{array}{c}\text { Lower limit of DC voltage } \\
\text { (EDC_Min) }\end{array}$ & $0.75 \mathrm{kV}(50 \%)$ \\
\hline $\begin{array}{c}\text { Short circuit parameter of } \\
\text { protective device for over } \\
\text { voltage }\end{array}$ & $0.2 \mathrm{ohm}$ \\
\hline
\end{tabular}

STATCOM can enhance the transient stability and significantly minimize the blade-shaft torsion oscillation of wind turbine generators [4, 7-10]. The reactive power of a STATCOM is produced by means of power electronic equipment of the voltage source converter (VSC) type. The VSC converts the dc voltage into a three-phase set of output voltages with desired amplitude, frequency and phase. The control scheme for the STATCOM is shown in Figure 12, where the d-axis current controls the STATCOM DC-link voltage to a constant value of $1.0 \mathrm{pu}$, while the q-axis current controls the reactive power of the STATCOM to maintain a terminal (grid) voltage of $1.01 \mathrm{pu}$. Figure 13 shows the schematic diagram for the STATCOM switching circuit, where the triangular carrier signal is used for the PWM operation, while Table 3 displays the parameters of the STATCOM.

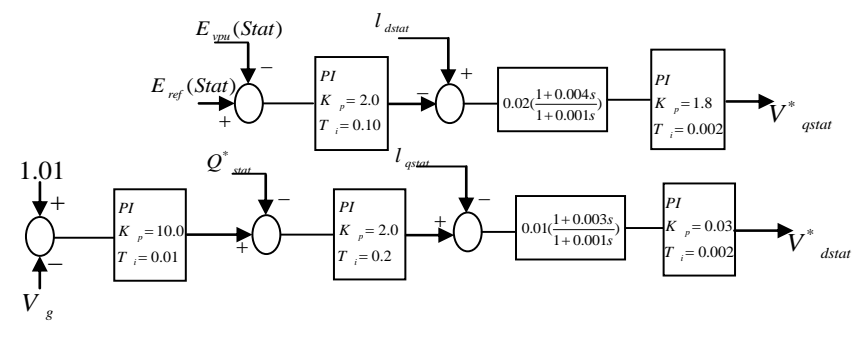

Figure 12. Control block for STATCOM

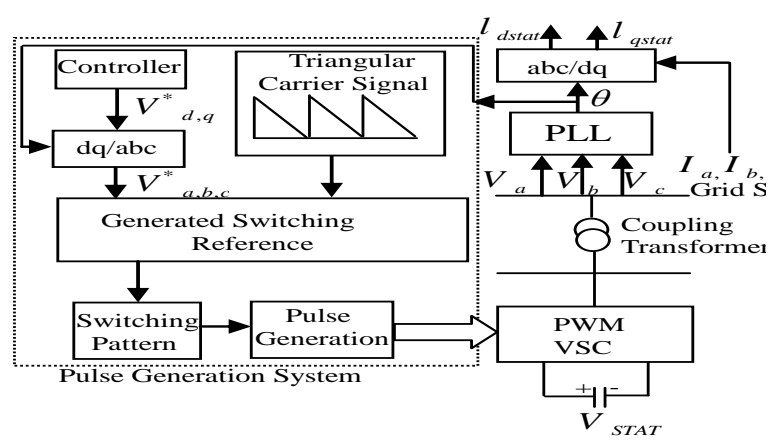

Figure13. Schematic diagram of a STATCOM switching circuit

Table 3. Parameters of STATCOM

\begin{tabular}{|l|l|}
\hline DC link voltage & $6.6 \mathrm{kV}$ \\
\hline Dc link capacitor & $50,000 \mu \mathrm{F}$ \\
\hline $\begin{array}{l}\text { Device for power } \\
\text { converter }\end{array}$ & IGBT \\
\hline PWM carrier frequency & $1.05 \mathrm{kHz}$ \\
\hline Rated Power & $12.5 \mathrm{MVA}$ \\
\hline Rated Voltage & $3.50 \mathrm{kV}$ \\
\hline
\end{tabular}

\section{SIMULATION RESULTS}

Simulations are carried out by using PSCAD/EMTDC for the three cases with different real wind speed data obtained from Hokkaido Island, Japan, for each generator (Figure 14). The response of the wind farm to wind speed change are shown in Figures 15-18. The wind farm responses during grid fault are given in Figures 19 and 20 where simulations were run for $10 \mathrm{sec}$. with three phase fault applied at $0.1 \mathrm{sec}$, as shown in the model system, and the circuit breakers on the faulted line were opened and reclosed at $0.2 \mathrm{sec}$ and $1.0 \mathrm{sec}$ respectively.

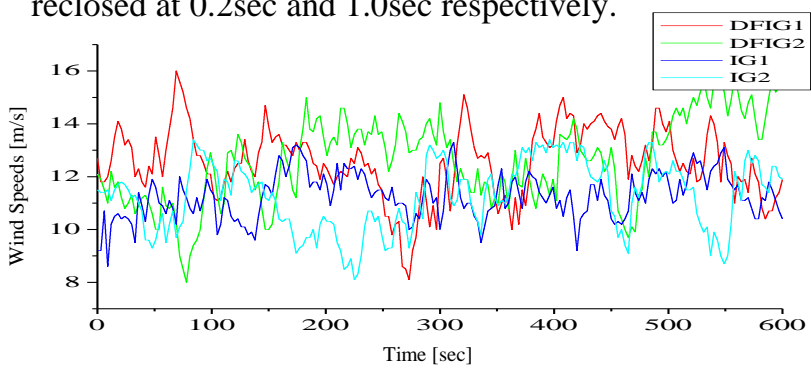

Figure 14. Wind speed data for DFIGs and IGs 


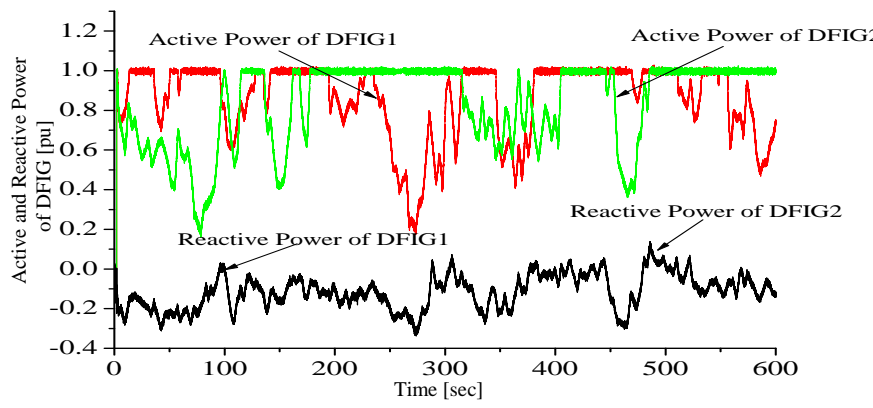

Figure 15. Active and reactive power of DFIGs (Case 1)

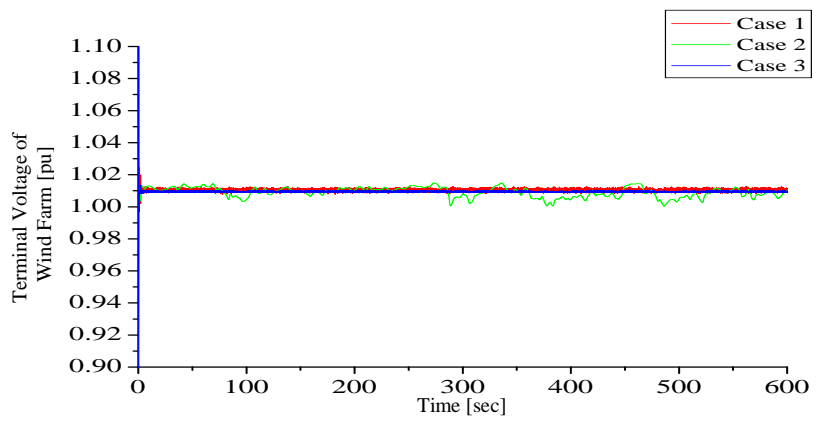

Figure 16. Terminal voltage of wind farm (Dynamic analysis)

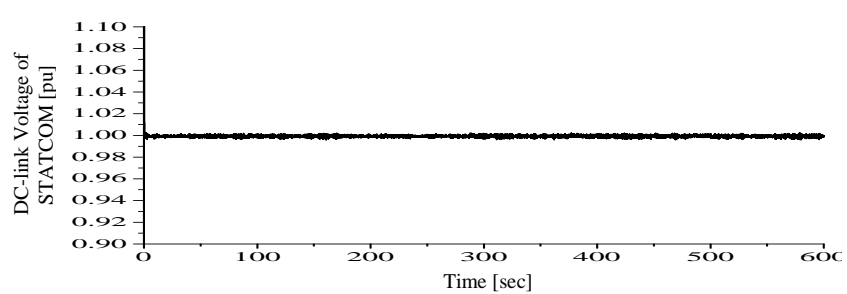

Figure 17. DC link voltage of STATCOM (Case 3)

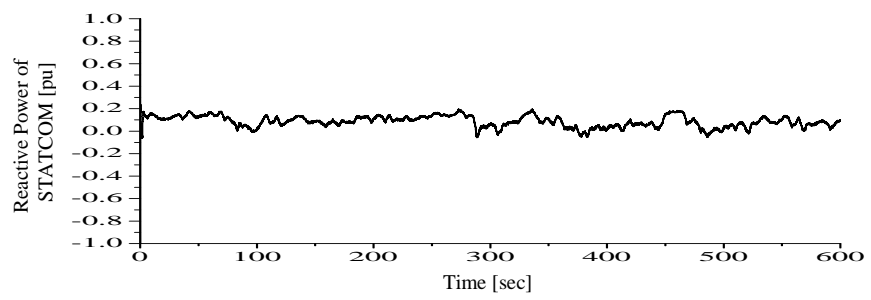

Figure 18. Reactive power of STATCOM (Case 3)

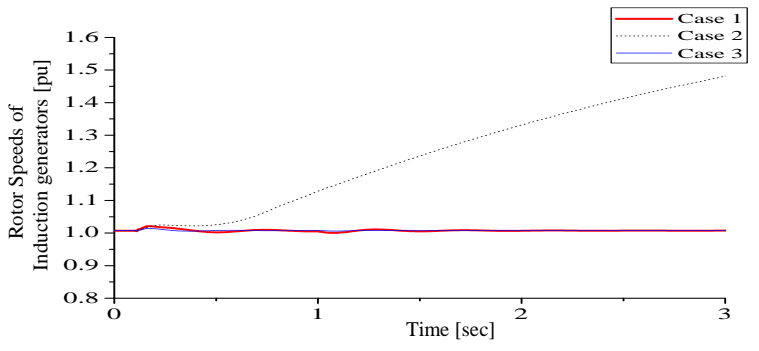

Figure 19. Rotor speed of induction generators

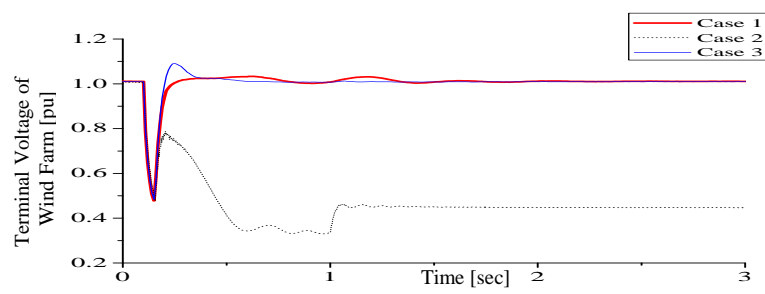

Figure 20. Terminal voltage of wind farm (Transient analysis) Electron, vol. 53, no.5, pp. 1521, 2006.
The simulation results show that the DFIGs and the STATCOM (cases 1 and 3) systems can effectively stabilize the wind farm by providing/absorbing necessary reactive power to/from the system. However, the DFIGs system seems to be more advantageous because, apart from generating electric power at steady state, it can also stabilize the wind farm during steady state and transient conditions

\section{CONCLUSION}

A comparative analysis of using DFIGs and STATCOM to stabilize a wind farm has been investigated. The DFIGs system offer more advantage than that of the STATCOM system because it generates electric power in steady state and at the same time, stabilizes the wind farm during network disturbance, through provision of reactive power by their frequency converters at reduced cost, without external compensation compared to the STATCOM system.

\section{ACKNOWLEDGMENT}

The first author would like to acknowledge Japan Gas Corporation Scholarship Foundation (JGC-S)/NIKISANEYOSHI for their kindly support in this work.

\section{REFERENCES}

[1] S. Heir, Grid Integration of Wind Energy Conversion Systems, ISBN: 0471-97143, 1998

[2] A.D. Hassan, and G. Michalke, "Fault Ride-Through Capacity of DFIG Wind Turbines, "Renewable Energy, Vol. 32, pp. 1594-1610, 2007.

[3] I. Erlich, H. Wrede and C. Feltes, "Dynamic behavior of DFIG-based wind turbine during grid faults," IEEJ Trans. vol 128, no. 4, pp. 396-401, 2008.

[4] S.M. Muyeen, M.A. Mannan, M.H.Ali, R. Takahashi, and J.Tamura, "Stabilization of Wind Turbines Generator System by STATCOM," IEEJ Transaction on Power and Energy, vol. 126-B, no. 10, pp. 1073-1082, 2006.

[5] "PSCAD/EMTDC Manual," Manitoba HVDC Research Center, 1994.

[6] R. Takahashi, J. Tamura, M. Futami, M. Kimura and K. Idle, "A New Control Method for Wind Energy Conversion System Using Double Fed Synchronous Generators," IEEJ Trans. Power and Energy, Vol.126, no. 2, pp. 225-235, 2006

[7] J.A. Suul, M. Molinas and T. Undeland, "STATCOMbased indirect torque control of induction machines during voltage recovery after grid faults," IEEE Trans. on Power Electronics, vol. 25, no. 5, pp. 1240-1250, 2010

[8] L. Zhang, C. Shen, M.L. Crow, L. Dong, S. Pekarek and S. Atcitty, "Performance indices for the dynamic performance of FACTS and FACTS with energy storage," Elect. Power Compon. Syst., vol 33, no. 3, pp. 299-314, 2005.

[9] Z. Yang, C. Shen, L. Zhang, M.L. Crow, and S. Atcitty, "Integration of STATCOM and battery energy storage ," IEEE Trans. Power System., vol 16, no. 2, pp. 254-260, 2001.

[10] Y. Cheng, C. Qian, M.L Crow, S. Pekarek and S. Atcitty, "A Comparison of diode-clamped and cascaded multilevel converters a STATCOM with energy storage," IEEE Trans. Ind 